\title{
SCIDiC
}

\author{
International Journal of Dentistry and Oral Science (IJDOS) \\ ISSN: 2377-8075
}

\section{Targeted Phytotherapy For Reactive Oxygen Species Linked Oral Cancer}

Research Article

\author{
Nikita Sivakumar ${ }^{1}$, R. V. Geetha ${ }^{2}$, Vishnu Priya ${ }^{3}$, Gayathri R ${ }^{4}$, Dhanraj Ganapathy ${ }^{5 *}$ \\ ${ }^{1}$ Intern, Department of Prosthodontics, Saveetha Dental College and Hospitals, Chennai - 600 077, India. \\ 2 Assistant Professor, Department of Microbiology, Saveetha Dental College and Hospitals, Chennai - 600077 , India. \\ ${ }^{3}$ Professor and Head, Department of Biochemistry, Saveetha Dental College And Hospitals, Saveetha Institute Of Medical And Technical Sciences \\ Chennai, India. \\ ${ }^{4}$ Reader, Department of Physiology, Saveetha Dental College and Hospitals, Chennai - 600 077, India. \\ ${ }^{5}$ Professor and Head, Department of Prosthodontics, Saveetha Dental College And Hospitals, Saveetha Institute Of Medical And Technical Sciences \\ Chennai, India.
}

\section{Abstract}

\begin{abstract}
Medicinal plants play a major role in medical and health needs. In developing countries, there is an increasing attempt to incorporate the traditional medicines, especially herbal preparations in the local healthcare systems and people are increasingly turning to herbal medicine. Plant derived therapies are suggested for its cost effectiveness, fewer side effects and lesser frequencies of resistance. The aim of this study is to understand the free radical scavenging properties of selected Indian medicinal plants and their cytotoxicity against oral cancer cell lines.The plant parts were shade dried, powdered and extracted using methanol solvent. These extracts were analyzed for the free radical scavenging properties in Cell lines by Nitric oxide assay. Further, an MTT assay was performed to understand the cytotoxicity of the extracts. Data showed a significant percentage of inhibition of the free radicals and cytotoxicity against the oral cancer cell lines.Selected plants have been shown to possess inhibitory potentials against ROS-linked oral cancers and may be used for targeted phytotherapy.
\end{abstract}

Keywords: Phytotherapy; Herbal; ROS; Cytotoxicity; Cancer; Free Radicals.

\section{Introduction}

The great advances in medicine for synthetic drugs, might have made us overlook the healing power of a "natural" source; the plants [14]. However, since the consumer's interest is gradually shifting towards the more "natural" and "safer" alternative, Phytotherapy has once again come back to its peak of research [8].

In this research, two plant extracts will be used; Cassia fistula and Cassia alata. They belong to the same family, Fabaceae [4]. Cassia alata which is also known as Sennaalata, is a medicinal plant used as vermicide, astringent, purgative, expectorant and to treat skin diseases. It has demonstrated effective broad spectrum antibacterial, anticandidal, and antifungal activities in several laboratory studies over the years [12]. It also relieves pain, reduces inflammation, helps in digestion and repels insects. The parts commonly used for medicinal purposes are the leaves and the bark $[18,6]$.

On the other hand, Cassia Fistula also has various medicinal uses. It is commonly known as Amaltas. They are native to South-East Asia and generally found in the Himalayas [20]. Cassia Fistula true in a whole is very useful; the root bark contains tannin, phlobaphenes and oxy anthraquinone, the pulp containing rhein, a volatile oil and a resinous substance and notably the fruits of cassia fistula are used in the Indian Pharmaceutical codex. Cassia Fistula extracts are commonly used to treat Aguesia, skin disorders, intestinal disorders, common cold and constipation [1].

Reactive oxygen species (ROS) may be stimulated by oxidative stress, nutrient starvation, mitochondrial toxins and hypoxia which eventually induces carcinogenesis [2]. In this research, two plant extracts will be used to study its phytochemical analysis and its role in phytotherapy for reactive oxygen species linked to oral

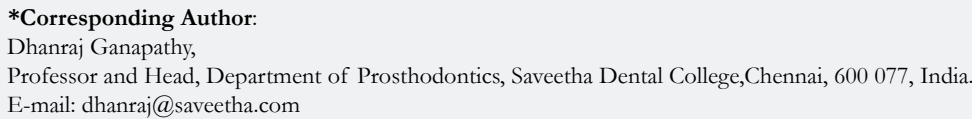

Citation: Nikita Sivakumar, R. V. Geetha, Vishnu Priya, Gayathri R, Dhanraj Ganapathy. Targeted Phytotherapy For Reactive Oxygen Species Linked Oral Cancer. Int J Dentistry Oral Sci. 2021;8(1):1425-1429. doi: http://dx.doi.org/10.19070/2377-8075-21000284

Copyright: Dhanraj Ganapathy ${ }^{\circ} 2021$. This is an open-access article distributed under the terms of the Creative Commons Attribution License, which permits unrestricted use, distribution and reproduction in any medium, provided the original author and source are credited. 
cancer $[17,10]$.

\section{Materials And Method}

Fresh Leaves of Cassia alata and Cassia fistula were collected, shade dried and powdered. The powdered (100gm) was extracted three times by Cold percolation method with $300 \mathrm{ml}$ of Methanol at room temperature for $72 \mathrm{hrs}$. The filtrates were concentrated under reduced pressure at $40^{\circ} \mathrm{C}$ and stored in the refrigerator at $2-8^{\circ} \mathrm{C}$ for use in subsequent experiments.

The yield ( $\mathrm{g} / 100 \mathrm{~g}$ of sample) of the C.alata and C.fistula extracts were $4.915 \mathrm{~g}$ and $3.496 \mathrm{~g}$ respectively.

In this research, 3 analyses were carried out; Phytochemical Tests, Nitric Oxide Assay and MTT assay.

\section{Phytochemical Tests}

The phytochemical tests included tests for carbohydrates, tannins, saponins, flavonoids, alkaloids, quinones, glycosides, cardiac glycosides, terpenoids, Steroids and phytosteroids, phenols, coumarins, Phlobatannins, Anthraquinones.

\section{Test for Carbohydrates:}

To $2 \mathrm{ml}$ of plant extract, $1 \mathrm{ml}$ of Molisch's reagent and few drops of concentrated sulphuric acid were added. Presence of purple or reddish color indicates the presence of carbohydrates [15].

\section{Test for Tannins:}

To $1 \mathrm{ml}$ of plant extract, $2 \mathrm{ml}$ of $5 \%$ ferric chloride was added. Formation of dark blue or greenish black indicates the presence of tannins [19].

\section{Test for Saponins:}

To $2 \mathrm{ml}$ of plant extract, $2 \mathrm{ml}$ of distilled water was added and shaken in a graduated cylinder for 15 minutes lengthwise. Formation of $1 \mathrm{~cm}$ layer of foam indicates the presence of saponins [5]. Test for Flavonoids

To $2 \mathrm{ml}$ of plant extract, $1 \mathrm{ml}$ of $2 \mathrm{~N}$ sodium hydroxide was added. Presence of yellow color indicates the presence of flavonoids.

\section{Test for Cardiac Glycosides:}

To $0.5 \mathrm{ml}$ of extract, $2 \mathrm{ml}$ of glacial acetic acid and few drops of $5 \%$ ferric chloride were added. This was under layered with $1 \mathrm{ml}$ of concentrated sulphuric acid. Formation of brown ring at the interface indicates presence of cardiac glycosides.

\section{Test for Terpenoids:}

To $0.5 \mathrm{ml}$ of extract, $2 \mathrm{ml}$ of chloroform was added and concentrated sulphuric acid was added carefully. Formation of red brown color at the interface indicates presence of terpenoids.

6. Test for Phlobatannins:
To $1 \mathrm{ml}$ of plant extract few drops of $2 \%$ HCL was added; the appearance of red color precipitate indicates the presence of phlobatannins.

\section{Test for Anthraquinones:}

To $1 \mathrm{ml}$ of plant extract few drops of $10 \%$ ammonia solution was added, appearance pink color precipitate indicates the presence of anthraquinones [9].

\section{Test for Alkaloids:}

To $2 \mathrm{ml}$ of plant extract, $2 \mathrm{ml}$ of concentrated hydrochloric acid was added. Then few drops of Mayer's reagent were added. Presence of green color or white precipitate indicates the presence of alkaloids [16].

\section{Test for Quinones:}

To $1 \mathrm{ml}$ of extract, $1 \mathrm{ml}$ of concentrated sulphuric acid was added. Formation of red color indicates the presence of quinones.

\section{Test for Phenols:}

To $1 \mathrm{ml}$ of the extract, $2 \mathrm{ml}$ of distilled water followed by few drops of $10 \%$ ferric chloride was added. Formation of blue or green color indicates presence of phenols.

\section{Test for CoumarinsL}

To $1 \mathrm{ml}$ of extract, $1 \mathrm{ml}$ of $10 \% \mathrm{NaOH}$ was added. Formation of yellow color indicates presence of coumarins [21].

\section{Test for Glycosides:}

To $2 \mathrm{ml}$ of plant extract, $3 \mathrm{ml}$ of chloroform and $10 \%$ ammonia solution was added. Formation of pink color indicates presence of glycosides [3].

\section{Tests for Steroids and Phytosteroids:}

To $1 \mathrm{ml}$ of plant extract equal volume of chloroform is added and subjected with few drops of concentrated sulphuric acid appearance of brown ring indicates the presence of steroids and appearance of bluish brown ring indicates the presence of phytosterols. [13].

\section{Nitric Oxide Assay}

The nitric oxide assay was performed as described previously with slight modification. After pre-incubation of $\mathrm{KB}$ cells $(1.5 \times$ 105 cells $/ \mathrm{mL})$ with LPS $(1 \mu \mathrm{g} / \mathrm{ml})$ for $24 \mathrm{~h}$, the plant extracts were added and incubated for $48 \mathrm{~h}$.

The quantity of nitrite in the culture medium was measured as an indicator of NO production. Amount of nitrite, a stable metabolite of NO, was measured using Griess reagent (1\% sulfanilamide and $0.1 \%$ naphthylethylenediaminedihydrochloride in $2.5 \%$ phosphoric acid). Briefly, $100 \mu$ l of cell culture medium was mixed with $100 \mu \mathrm{l}$ of Griess reagent. Subsequently, the mixture was incubated at room temperature for $10 \mathrm{~min}$ and the absorbance at $540 \mathrm{~nm}$ was measured in a microplate reader (Tecan, Switzerland). Fresh 
culture medium was used as a blank in every experiment [22].

$\%$ of inhibition $=($ Control OD-Sample OD $) /$ Control OD X 100.

\section{The MTT Assay}

The MTT assay (Mossman, 1983) is based on the ability of live but not dead cells to reduce a yellow tetrazolium dye to a purple formazan product. Cells were maintained in DMEM medium, supplemented with 10\% Fetal Bovine Serum, at 37oC in humidified atmosphere with $5 \% \mathrm{CO}_{2}$. The cells were plated in 96 well flat bottom tissue culture plates at a density of approximately $1.2 \mathrm{X}$ 104 cells/well and allowed to attach overnight at $37^{\circ} \mathrm{C}$. The medium was then discarded and cells were incubated with different concentrations of the C.fistula extract $(25,50,75,100 \& 150 \mu \mathrm{g})$ for 24 hours. After the incubation, medium was discarded and $100 \mu \mathrm{l}$ fresh medium was added with $10 \mu \mathrm{l}$ of MTT $(5 \mathrm{mg} / \mathrm{ml})$. After 4 hours, the medium was discarded and $100 \mu$ l of DMSO was added to dissolve the formazan crystals. Then, the absorbance was read at $570 \mathrm{~nm}$ in a microtiter plate reader. Cyclophosphamide was used as positive control.

Cell survival was calculated by the following formula:

Viability $\%=($ Test OD / Control OD) X 100

Cytotoxicity $\%=100-$ Viability $\%$

\section{Results}

Tables and Figures.

Table 1. Shows Phytochemical Tests.

\begin{tabular}{|c|c|c|c|}
\hline S.No & Phytochemical Tests & C.alataMetOH & C.fistulaMetOH \\
\hline 1 & Carbohydrates & + & + \\
\hline 2 & Tannins & + & + \\
\hline 3 & Saponins & - & - \\
\hline 4 & Flavonoids & + & + \\
\hline 5 & Alkaloid & - & - \\
\hline 6 & Quinones & + & + \\
\hline 7 & Glycosides & - & - \\
\hline 8 & Cardiac glycosides & - & - \\
\hline 9 & Terpenoids & + & + \\
\hline 10 & Phenols & + & + \\
\hline 11 & Coumarins & - & - \\
\hline 12 & Steroids and Phytosteroids & - & - \\
\hline 13 & Phlobatannins & - & - \\
\hline 14 & Anthraquinones & - & \\
\hline
\end{tabular}

(+)Present; (-) Absent

Figure 1. Shows C.alata Methanol.

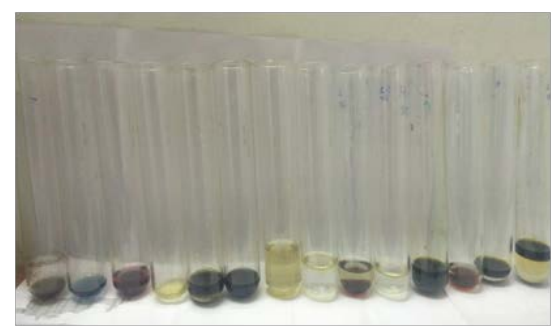

Figure 2. Shows C.fistula Methanol.

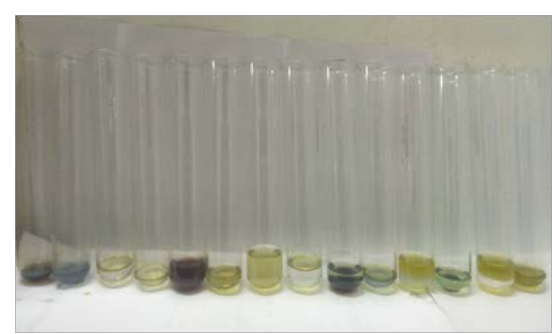


Figure 3. Shows NO assay comparison in inhibition.

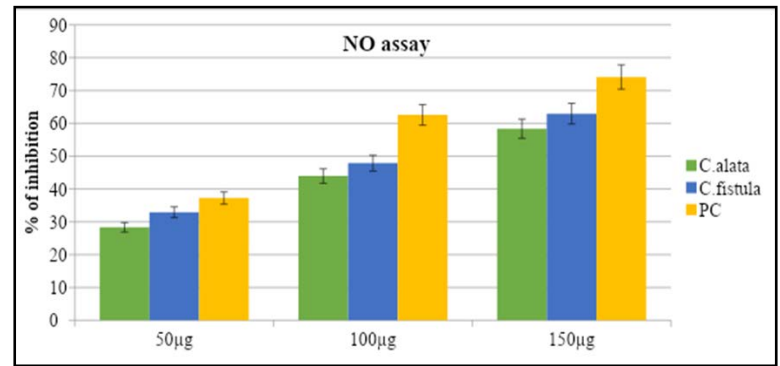

Table 2. Shows Nitric Oxide Assay.

\begin{tabular}{|c|c|c|c|}
\hline \multicolumn{4}{|c|}{$\%$ inhibition } \\
\hline Concentration & C.alata & C.fistula & PC \\
\hline $50 \mu \mathrm{g}$ & 28.34 & 32.91 & 37.24 \\
\hline $100 \mu \mathrm{g}$ & 43.94 & 47.86 & 62.56 \\
\hline $150 \mu \mathrm{g}$ & 58.37 & 62.94 & 74.11 \\
\hline
\end{tabular}

Table 3. Shows MTT Assay.

\begin{tabular}{|c|c|c|}
\hline \multicolumn{3}{|c|}{ Viability } \\
\hline Concentration $(\boldsymbol{\mu g})$ & C.fistula & PC \\
\hline 25 & 72.33 & \\
\hline 50 & 57.29 & \\
\hline 100 & 49.88 & 4.87 \\
\hline 125 & 45.17 & \\
\hline 150 & 34.64 & \\
\hline
\end{tabular}

Table shows cell viability of Sample and Positive control in KB cell line.

Table 4. Shows cytotoxicity of Sample and Positive control in KB cell line.

\begin{tabular}{|c|c|c|}
\hline \multicolumn{3}{|c|}{ Cytotoxicity } \\
\hline Concentration $(\boldsymbol{\mu g})$ & C.fistula & PC (50 $\boldsymbol{\mu g})$ \\
\hline 25 & 27.67 & \\
\hline 50 & 42.71 & \\
\hline 100 & 50.12 & 95.13 \\
\hline 125 & 54.83 & \\
\hline 150 & 65.36 & \\
\hline
\end{tabular}

PC- Positive control (Cyclophosphamide)

Figure 4. Shows cell viability of sample in KB cell line.

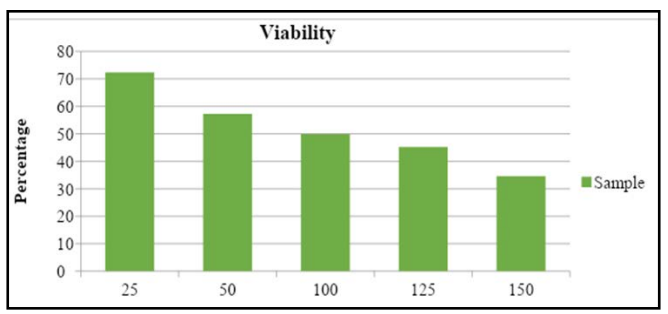

\section{Discussion}

Preliminary phytochemical analysis of methanolic extract of Cassia alata and Cassia fistula was performed using standard tests. The phytoconstituents present in Cassia fistula and Cassia alata were found to be carbohydrates, tannins, flavonoids, quinones, terpenoids, coumarins and phenols. Herbal extracts contains many secondary metabolites, which contribute significantly towards the biological activities of medicinal plants such as hypoglycemic, an- 
Figure 5. Shows cytotoxicity of sample in KB cell line.

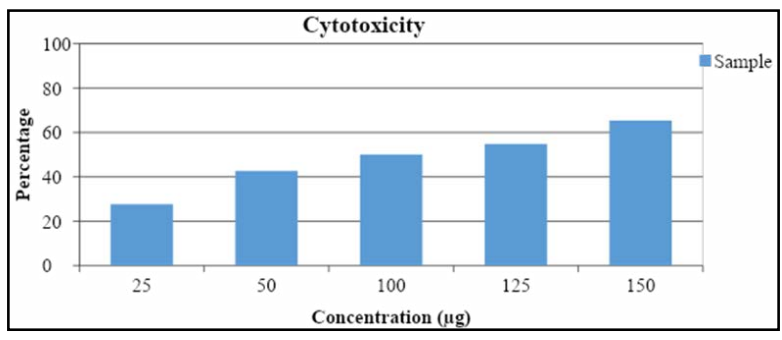

tidiabetic, antioxidant, antimicrobial, anti-inflammatory, anti carcinogenic, antimalarial, anticholinergic, anti leprosy activities etc. [11]. There is more to explore of the properties of Cassia Fistula and Cassia Alata extracts which may be a thrust area for the future research in the drug designing industry.

Nitric Oxide is an inhibitor of neuronal signaling, platelet aggregation and regulated cell mediated toxicity. It is a free radical species present in tissues. The ability of these two plants extracts in scavenging Nitric Oxide radical was evaluated and it was found that Cassia fistula has better scavenging capacity when compared with Cassia alata.

Cytotoxicity analysis by using varying concentration of Cassia fistula and Cassia alata extract was done. MTT assay is a colorimetric assay for all cell metabolic activities. NAD (P) $\mathrm{H}$ dependent cellular oxide-reduction enzymes may, under defined conditions, reflect the number of viable cells present.

Examples of few commercially used extracts are Chamomillarecutita for its property of mild gastrointestinal complaints and PunicaGranatum for chronic periodontitis. Other few essential phytotherapy products are such as lemon grass oil which has shown its significance as an antidiabetic and antioxidant agent. In addition to that, Achyranthes aspera leaf extracts have shown anthelmintic activity which has a purpose of fighting against parasites which cause the development of diseases such as tuberculosis and malaria [7].

\section{Conclusion}

Screening of the two medicinal plants clearly reveals that the maximum classes of phytoconstituents are present in Cassia fistula and Cassia alata. Hence, the above plant extract could be explored for its highest therapeutic efficacy by pharmaceutical companies in order to develop safe drugs for various ailments. Further research and development can be done for better understanding of their therapeutic effect.

The extracts exhibited increasing cytotoxicity with increasing concentration. This study confirms the antioxidant and cytotoxicity potential of Cassia Fistula and Cassia Alata extracts. There is more to explore of the properties of Cassia fistula and Cassia alata extracts which may be a thrust area for the future research in the drug designing industry.

\section{References}

[1]. Bahorun T, Neergheen, VS, Aruoma, OI. 'Phytochemical constituents of Cassia fistula', African Journal of Food, Agriculture, Nutrition and Development.2011.doi: 10.4314/ajfand.v4i13.71772.
[2]. Bhalodia NR, Shukla VJ. Antibacterial and antifungal activities from leaf extracts of Cassia fistula 1.: An ethnomedicinal plant. J Adv Pharm Technol Res. 2011 Apr;2(2):104-9.Pubmed PMID: 22171301.

[3]. Dontha, S, Kamurthy H, Manthripragada, B.'Phytochemical Screening and Evaluation of in-vitro Anti-oxidant Activity of Extracts of Ixorajavanica D. C Flowers', American Chemical Science Journal.2016; 1-9. doi: 10.9734/ acsj/2016/20661.

[4]. Van Dyck E, Meheus A, Piot P. Laboratory diagnosis of sexually transmitted diseases. World Health Organization; 1999.

[5]. Farnsworth NR, Loub WD, Blomster RN, Gorman M. Pericyclivine, a new Catharanthus alkaloid. J. Pharm. Sci. 1964 Dec 1;53(12):1558.

[6]. Habtemariam S. Medicinal foods as potential therapies for Type-2 diabetes and associated diseases: the chemical and pharmacological basis of their action. Academic Press; 2019 Jun 8.

[7]. Hasan K, Lakshmi T, Rathinam TK. Preliminary Phytochemical Analysis and In vitro Anti-helmenthic activity of Achyranthesaspera Leaf extract. Pharmacogn. J. 2015;7(6):397-399.

[8]. Heinrich M, Williamson EM, Gibbons S, Barnes J, Prieto-Garcia J. Fundamentals of Pharmacognosy and Phytotherapy E-Book. Elsevier Health Sciences; 2017 Nov 24

[9]. Jana S, Shekhawat GS. Phytochemical analysis and antibacterial screening of in vivo and in vitro extracts of Indian medicinal herb: Anethumgraveolens. Res J. Med. Plants . 2010;4(4):206-12.

[10]. Jothy SL, Zakariah Z, Chen Y, Sasidharan S. In vitro, in situ and in vivo studies on the anticandidal activity of Cassia fistula seed extract. Molecules. 2012 Jun 7;17(6):6997-7009.Pubmed PMID: 22678414. https://pubmed. ncbi.nlm.nih.gov/22678414/

[11]. Karpagam GN, Gayathri R, Vishnupriya V. Bioactivity analysis of lemongrass oil. Asian J. Research Chem. 2016 Jul 1;9(7):903.

[12]. Khan MR, Kihara M, Omoloso AD. Antimicrobial activity of Cassia alata. Fitoterapia. 2001 Jun 1;72(5):561-4.

[13]. Kolawole OM, Oguntoye SO, Agbede O, Olayemi AB. Studies on the efficacy of Brideliaferrugineabenth bark extract for domestic wastewater treatment. Bull ChemSoc Ethiop. 2007 Jul 10;21(2):205-11

[14]. Mills S, Bone K. Principles and practice of phytotherapy. Modern herbal medicine. Churchill Livingstone; 2000.

[15]. Muńoz K, Maciuk A, Bravo K, Londońo J, Osorio E, Figadère B. Screening of Colombian plants for antimalarials using LC-Bio-MS. Planta Med. 2008 Jul;74(09):PC86.

[16]. Nayik GA, Gull A. Antioxidants in Vegetables and Nuts-Properties and Health Benefits. Springer Singapore Pte. Limited.2020.

[17]. Nuijts RM, Nuijts RM. Ocular toxicity of intraoperatively used drugs and solutions. Kugler Publications; 1995.

[18]. Panda SK, Padhi LP, Mohanty G. Antibacterial activities and phytochemical analysis of Cassia fistula (Linn.) leaf. J Adv Pharm Technol Res. 2011 Jan;2(1):62-7.Pubmed PMID: 22171295.

[19]. Richardson PM. Phytochemical methods: a guide to modern techniques of plant analysis. Brittonia. 1990;2(42):115.

[20]. Varghese GK, Bose LV, Habtemariam S. Antidiabetic components of Cassia alata leaves: identification through $\alpha$-glucosidase inhibition studies. Pharm. Biol. 2013 Mar 1;51(3):345-9.

[21]. Wisniak J. The chemistry and technology of jojoba oil. Am Oil Chem Soc. 1987.

[22]. Xie G, Schepetkin IA, Siemsen DW, Kirpotina LN, Wiley JA, Quinn MT. Fractionation and characterization of biologically-active polysaccharides from Artemisia tripartita. Phytochemistry. 2008 Apr;69(6):1359-71.Pubmed PMID: 18325553. 